\title{
NILAI-NILAI DALAM RITUAL BASARAH
}

\author{
Wentin, S.Ag., M.Pd.H
}

\begin{abstract}
Abstact
Devotion to God is a necessity for every religious person. Hindus explain the teachings of Bhakti in the Bhagavata Purana known as Navavida Bhakti.The actualization of devotional service in Hinduism has diversity but is essentially the same. Therefore, there are differences in the practice of devotional service for Hindus in various regions.This happened to Hinduism in Central Kalimantan (Hindu Kaharingan).This paper describes four important things related to the implementation of the Basarah for Hindu Kaharingan in Central Kalimantan. The four things are basarah philosophy, the procedure of basarah, sajen basarah, and the values contained in the implementation of basarah.
\end{abstract}

Keywords: Bhakti yoga, basarah philosophy, tatacara basarah, sajen basarah, Basarah Values

\section{Pendahuluan}

Kehidupan keberagamaan manusia senantiasa dicirikan hadirnya sosok "Tuhan". Ia diyakini sebagai awal dan sekaligus akhir perjalanan kehidupan. Manusia juga meyakini bahwa dirinya bersumber dari-Nya. Karenya, manusia memiliki relasi yang tidak terpisahkan dalam banyak hal. Relasi tersebut secara metaforis mirip seorang ayah dengan putranya.Maka tidak mengherankan jika dalam wilayah kerohanian manusia senantiasa membangun ketidak-terpisahan dengan Tuhan, seperti seorang anak yang tidak ingin lepas dari pelukan sang ayah. M anusia senantiasa merindukan Tuhannya. Pemandangan itu lebih terlihat jelas bila manusia sedang dalam ketidakberdayaan. Sembahyang, sebagaimana yang kita lihat dalam praktik-praktik keberagamaan merupakan tanda kerinduan itu.

Salah satu ciri orang beragama adalah melakukan pemujaan kepada Tuhan. Secara umum kegiatan pemujaan itu disebut sembahyang. Meskipun sembahyang merupakan ciri umum dari orang yang beragama, tetapi apa motif orang melakukan sembahyang tidaklah sama. Seperti dijelaskan dalam Bhagavad Gita 7.16:

Catur-vidha bhajante mam janah sukrtino 'rjuna arto jijnasur artharthi jnani ca bharatarsabha

Terjemahan :

$O$ yang paling baik di antara para Bharata, empat jenis orang saleh mulai ber-bhakti kepada-Kuorang yang berduka cita, orang yang menginginkan kekayaan, 
orang yang ingin tahu, dan orang yang mencari pengetahuan tentang yang mutlak.

Jenis-jenis orang yang diuraikan dalam ayat ini bukanlah orang jahat. Mereka mengikuti prinsip-prinsip yang mengatur dari Kitab-kitab suci. Mereka disebut sukrtinah, atau orang yang mematuhi aturan dan peraturan kitab suci, hukum moral dan hukum masyarakat, dan mereka kurang lebih setia kepada Tuhan. Di kalangan para sukrtinah ada empat golongan, yaitu orang yang kadang-kadang berduka cita, orang yang membutuhkan uang, orang yang kadang-kadang ingin tahu, dan orang yang kadang-kadang mencari pengetahuan tentang kebenaran mutlak. Empat jenis orang tersebut mendekati Tuhan untuk ber-bhakti dalam berbagai keadaan. Mereka belum menjadi penyembah yang murni, sebab mereka mempunyai cita-cita yang harus dipenuhi sebagai balasan bhakti. Bhakti yang murni bebas dari cita-cita dan bebas dari keinginan untuk mendapatkan keuntungan material. Dalam Bhakti-rasamrta-sindhu (1.1.11), bhakti yang murni diuraikan sebagai berikut :

anyabhilasita-sunyam

jnana-karmady-anavrtam

anukulyena krsnanu

silanam bhaktir utama

Terjemahan :

Orang harus melakukan cinta- bhakti rohani kepada Tuhan dengan cara yang menguntungkan dan bebas dari keinginan untuk laba material melalui kegiatan yang dimaksudkan untuk membuahkan hasil atau anganangan filsafat. Itulah yang disebut bhakti yang murni (Prabhupada, 2006:386-389).

Selain keragaman motif dalam pelaksanaan sembahyang seperti yang terurai di atas, sembahyang juga memiliki tata cara pelaksanaan yang berbeda-beda, tetapi tujuan tertinggi dari pelasanaan sembahyang adalah sama, yaitu mencapai persatuan dan kesatuan dengan Tuhan. Kata sembahyang berasal dari bahasa Jawa Kuno. Sembah dalam bahasa Jawa Kuno yang berarti "menyayangi, menghormati, memohon, menyerahkan diri dan meyatukan diri. Sedangkan kata "hyang" artinya suci. Dengan demikian "sembahyang" berarti menyembah yang suci. Diantara yang suci itu yang maha suci adalah Tuhan. Tujuan tertinggi dari sembahyang itupun dirumuskan dengan rumusan yang berbeda-beda juga. Hakekat sembahyang sebagai langkah awal untuk meningkatkan harkat dan martabat kehidupan manusia (Wiana, 2007:5).

Pada kenyataannya semua agama mengajarkan umatnya memuja Tuhan secara individual dan dengan cara bersama-sama. Demikian juga agama Hindu mengenal juga sembahyang 
sendiri dan sembahyang secara bersamasama dalam kelompok. Sembahyang sendiri disebut Ekanta, dan sembahyang dengan cara bersama-sama atau kelompok disebut Samkirtanam. Manusia pada hakekatnya memiliki dua dimensi yaitu manusia sebagai makhluk individu dan manusia sebagai makhluk sosial. Sebagai makhluk individu manusia berhadapan dengan dirinya sendiri. Manusia berhadapan dengan kemauannya, cita-citanya, pasang surut prasaannya, daya nalar. Yang jelas setiap orang berhadapan dengan pertarungan kecenderungan kedewaan dan kecenderungan keraksasaan yang terus bertarung dalam dirinya. Pertarungan tersebut disebabkan oleh bertemunya purusa yang membawa chitta dengan predana yang membawa klesa. Orang akan mendapatkan keseimbangan diri apabila dirinya mampu mengendalikan chitta dan menguasai klesa. Chitta itu terdiri dari bhudi, manah dan ahamkara. kekuatan citta adalah dharma, jnana, wairagya dan aiswarya. empat kekuatan ini akan muncul apabila budhi yaitu kesadaran intelek menguasai manah atau pikiran, manah menguasai ahamkara atau ego.

Menurut Weda, makhluk hidup diciptakan menjadi dua golongan, yaitu yang suci (daivah) dan jahat (asurah). Seperti yang dijelaskan dalam Bhagawad Gita 16.6 sebagai berikut : Dvau bhuta-sargau loke 'smin daiva asura evaca

daivo vistarasah prokta

asuram partha me srnu

Terjemahan :

Wahai putera prtha, di dunia ini ada dua jenis makhluk yang diciptakan. Yang satu disebut suci dan yang lain jahat. Aku sudah menerangkan sifat-sifat suci kepadamu secara panjang lebar. Sekarang dengarlah dari-Ku tentang sifat-sifat jahat.

Para makhluk hidup yang terikat dibagi menjadi dua golongan di dunia ini. Orang yang dilahirkan dengan sifatsifat suci mengikuti kehidupan kehidupan yang teratur yaitu; mereka mematuhi aturan kitab suci. Sikap seperti ini disebut suci. Orang yang tidak mematuhi prinsip-prinsip yang mengatur sebagaimana tercantum dalam kitab suci dan bertindak menurut selera pribadi disebut jahat atau memiliki sifat asura. Tidak ada standar selain mematuhi prinsip-prinsip yang mengatur dari kitab suci. Disebutkan dalam kitab Veda bahwa para dewa dan orang jahat sama-sama dilahirkan dari prajapati. Satu-satunya perbedaan ialah bahwa golongan yang satu mematuhi aturan Veda sedangkan yang lain tidak (Prabhupada, 2006:743).

Hal senada juga dinyatakan dalam kitab Brhad-aranyaka Upanisad 1.3.1, berikut ini :

Dvaya ha prajapatyah, devas casuras ca tatah kaniyasa eva devah, 
jyayasa asurah

ta esu lokesv aspardhanta, te ha

deva ucuh

kantasuran yajna

udgithenatyayameti

Terjemahan :

Ada dua macam keturunan Prajapati, yaitu dewata dan asura. Dari keduanya dewata adalah yang lebih muda dan asura lebih tua. Mereka saling berlawanan untuk menguasai dunia ini. Para dewata berkata, ayo, marilah kita kalahkan para asura pada yajna melalui udgitha (Radhakrishnan, 1989:164).

Sebagai umat beragama yang memiliki keyakinan kepada Tuhan, umat Hindu Kaharingan yang berada di Kalimantan, khususnya Kalimantan Tengah juga memiliki kegiatan atau ritualistik persembahyangan. Kegiatan persembahyangan bagi umat Hindu Kaharingan umumnya disebut Basarah, yang memiliki arti "berserah" diri kepada Tuhan, Ranying Hatalla Langit. Berkaitan dengan ritualistik basarah bagi umat Hindu Kaharingan di Kalimantan Tengah, tulisan ini dimaksudkan untuk menilik kandungan nilai yang ada dalam pelaksanaan Basarah.

\section{Pembahasan}

\subsection{Ajaran Bhakti Yoga dalam} Veda

Pokok-pokok ajaran bhakti Yoga dapat kita jumpai dalam kitab suci Veda, menunjukkan bahwa sejak Veda diturunkan dan diterima oleh para maha rsi mengembangkan unsur bhakti dalam dirinya. Berikut ini adalah kutipan beberapa mantra-mantra Veda yang mengajarkan Bhakti Yoga, sebagai berikut:

Om bhur bhuvah svah Tat savitur varenyam Bhargo devasya dhimahi Dhiyo yo nah pracodayat

Terjemahan:

Ya Tuhan Yang Maha Esa, Sumber segala yang ada, luhur dan maha mulia, pencipta alam semesta. Kami memuja kemahamuliaan-Mu, anugerahkanlah kecerdasan dan budi pekerti yang luhur kepada kami (Yajurveda XXXVI.3).

Bhadram karnebhih srnuyama deva Bhadram pasyemaksabhir yajatrah Sthirair angais tustuvamsas tanubhir Vyasema hi devahitam yad ayuh

Terjemahan:

Ya Tuhan Yang Maha Esa, anugerahkanlah kepada kami untuk mendengar hal-hal yang baik dan ya Tuhan Yang Maha Suci, kami dapat melihat hal-hal yang baik dan semogalah kami dapat memersembahkan bhakti kami dengan kekuatan tangan dan keteguhan badan kami, dapat menikmati kebahagiaan sejati sesuai dengan hukum kemahakuasaan-Mu (Rgveda I.89.9, Yajurveda XXV.21).

\section{Purusa evedam sarvam Yad bhutam yacca bhavyam Utamrtatvasyesa no yad Annenati rohati}

Terjemahan:

Tuhan Yang Maha Esa adalah asal dari 
segala yang ada dan yang kan ada. Ia adalah raja dan penguasa alam yang kekal abadi dan dunia fana ini tempat tumbuhnya makanan (tanaman) (Rgveda X.90.2).

Isa vasyam idam sarvam Yat kim ca jagatyam jagat Tena tyaktena bhunjitha Ma grdhah kasya svid dhanam

Terjemahan:

Hendaknya dipahami bahwa segalanya diresapi oleh Tuhan Yang Maha Esa, segala yang bergerak dan yang tidak bergerak di alam semesta. Hendaknya orang tidak terikat dengan berbagai kenikmatan dan tidak rakus serta menginginkan milik orang lain (Yajurveda XI.1).

Agnim manye pitaram agnim apim Agnim bhrataram sadami tsakhayam, Agner anikam brhatah saparyam

Divi sukram yajatam suryasya

Terjemahan

Tuhan Yang Maha Esa yang kami yakini sebagai bapak kami, sanak kerabat dan saudara kami, kami puja Engkau sebagai yang memiliki wajah yang agung, sinar suci Surya di langit (Rgveda X.7.3).

Tvam eva mata ca pita tvam eva Tvam eva bandhus ca sakha tvam eva, Tvam eva vidya dravinam tvam eva Tvam eva sarvam mama deva-deva

Terjemahan:

Tuhan Yang Maha Esa sesungguhnya adalah ibu kami, bapak kami, sahabat kami dan keluarga kami. Tuhan Yang Maha Esa sesungguhnya pemberi pengetahuan dan Engkau penganugerah kekayaan. Engkau adalah segalanya, ya Engkau adalah dewata tertinggi daari seluruh dewata (Guru Stotra 14).
Dari beberapa mantram Veda yang mengajarkan bhakti ini, Maharsi Naradha dalam kitabnya Naradha Bhakti Sutra (I.2) merumuskan bahwa bhakti itu sesungguhnya parama prema atau parama premarupa, cinta kasih sejati, yang tertinggi. Kasih yang sejati digambarkan sebagai kasih dari seorang bapak, sanak saudara, sahabat dan di dalam Gurupuja, Tuhan Yang Maha Esa tidak saja digambarkan sebagai seorang ibu dan bapak, tetapi juga sebagai keluarga dan sahabat, pemberi pengetahuan dan kekayaan. berdasarkan penjelasan tersebut, maka pengertian bhakti seperti nampaknya dekat dengan yajna, yakni pengorbanan yang tulus dengan landasan kesucian hati dan berseminya kasih sayang. Selanjutnya dalam kitab Sabdakalpadruma III.463b, kata bhakti dinyatakan sebagai Vibhaga (pembagian atau pemisahan, memisahkan penyembah dan yang disembah), Seva (pemujaan atau pelayanan). Selanjutnya para ahli Sanskerta, menyatakan bahwa kata bhakti berasal dari akar kata bhaj yang berarti memuja, cinta kasih yang sejati kepada-Nya dengan penuh perasaan dan ketulusan. Di dalam Brahma Sutra atau Vedanta Sutra, pengertian tentang bhakti diungkapkan diungkapkan dalam kalimat sutra sebagai berikut : athatobhaktijijnasa, sekarang diuraikan makna bhakti, saparanuraktisvare, cinta kasih yang sejati kepada Tuhan Yang 
Maha Esa dari seseorang dengan sepenuh hati. Jadi pengertian tentang bhakti ini sejalan dengan makna kata parama prema kasih yang tinggi dan sejati (Titib, 2003).

Dalam Bhagawad Gita (Waswinara, 2008:16-17) kita jumpai penjelasan tentang empat orang yang berusaha mendekati diri, berbhakti kepada Tuhan Yang Maha Esa, yakni :

Catur-vidha bhajante mam Janah sukrtino 'rjuna, Arto jijnasur artharthi Jnani ca bharatasabha

Terjemahan:

The virtous ones who worship Me are of four kinds, the man in distress, the seeker for knowledge, the seeker for wealth and the man of wisdom, $O$ Lord of the Bharatas (Arjuna).

Tesam jnani nitya-yukta Eka-bhaktir visisyate, Priyo hi jnanino 'tyartham Aham sa ca mama priyah

Terjemahan:

Of these the wise one, who is ever in constant union with the Divine, whose devotion single-minded, is the best. For I am supremely dear to him and he is dear to $\mathrm{Me}$.

Keempat jenis orang yang berusaha mendekati Tuhan dapat dikategorikan dalam empat (4) jenis menurut Bhagawad Gita, yaitu orang yang sengsara, yang mengejar pengetahuan, yang mengejar kekayaan, dan yang terakhir adalah orang yang bijaksana/berbudi luhur. Diantara keempat macam orang tersebut, dinyatakan bahwa orang yang berbudhi luhur/bijaksana dikatakan sebagai yang paling mulia. Mengapa demikian, karena orang yang berbudhi luhur sepenuhnya menyerahkan diri kepadaNya. Penyerahan diri secara total ini disebut prapatti, demikianlah bhaktiprapatti mengandung makna bhakti yang murni, sebab mereka telah merasakan dalam kebhaktiannya itu, ia berada dalam lindungan-Nya. Bila kita bhakti dan menyerahkan diri sepenuh hati, maka Tuhan Yang Maha Esa hadir di hadapan kita, menganugerahkan sesuatu yang menjadi harapan kita dan melindungi yang kita miliki.

$$
\begin{gathered}
\text { Ananyas cintayanto Mam ye } \\
\text { janah paryupasate, Tesam } \\
\text { nityabhiyuktanam Yoga- } \\
\text { ksemam vahamy aham }
\end{gathered}
$$

Terjemahan

But those who worship Me, medidating on Me alone, to them who ever perserve, I Bring attainment of what they have not and security in what they have (Waswinara, 2008:322).

Ada dua jenis atau bentuk bhakti, yaitu para bhakti dan apara bhakti. Para bhakti mempunyai makna yang sama dengan prapatti, yakni penyerahan diri secara total kepada-Nya sedang apara bhakti adalah bhakti dengan pelbagai permohonan dan permohonan yang diangap wajar, misalnya keselamatan atau memohon berkembang-mekarnya budhi nurani, sedangkan permohonan 
untuk kekayaan dan kekuasaan, sering disebut bhakti yang bersifat rajas dan tamas. Perlu ditegaskan bahwa prapatti itu bukan fatalistik, artinya dengan penyerahan diri kepada-Nya, kemudian yang bersangkutan tidak bekerja sebagaimana tidak melakukan tugas dan kewajiban dengan baik. Tuhan Yang Maha esa di dalam kitab suci Veda tegas menyatakan bahwa Dia hanya menyayangi umat manusia yang suka bekerja keras dan tidak malas.

Ajaran bhakti dalam kitab Bhagavata Purana (VII.5.23) dikenal dengan Nawawidha Bhakti atauNavalaksana Bhakti adalah sembilan cara bhakti atau bentuk bhakti yang terjabarkansebagai berikut :

Sravanam kirtanam visnoh smaranam pada sevanam

Arcanam vandanam dasyam sakhyam atma nivedanam

Terjemahan:

Sembilan bentuk bhakti kepada Sang Hyang Visnu, yaitu (1). Sravanam, (2). Kirtanam, (3). Smaranam, (4). Pada

Sevanam, (5). Arcanam, (6). Vandanam, (7) Dasyam, (8). Sakhyam, (9). Atma Nivedanam (Titib, 2003:55)

Adapun penjelasan dari sloka di atas yaitu :

1. Sravanam, yaitu mempelajari keagungan Tuhan Yang maha Esa melalui membaca atau mendengarkan pembacaan kitab-kitab suci.

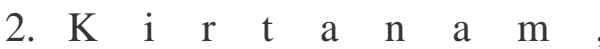

mengucapkan/menyanyikan nama-nama Tuhan Yang Maha Esa.

3. Smaranam, mengingat nama Tuhan atau meditasi tentangNya.

4. Padasevanam, memberikan pelayanan kepada Tuhan Yang Maha Esa, termasuk melayani, menolong pelbagai makhluk ciptaan-Nya

5. Arcanam, memuja keagunganNya umumnya dengan sarana arca dan persembahan air, bunga, biji-bijian, buah-buaha, dan sebagainya.

6. Vandanam, sujud bhakti kepada Tuhan Yang Maha Esa.

7. Dasya, melayani-Nya dengan pengertian mau melayani mereka yang memerlukan pertolongan dengan penuh keikhlasan, memandang mereka sebagai ciptaan-Nya.

8. Sakhya, memandang Tuhan Yang Maha Esa sebagai sahabat sejati, yang memeberikan pertolongan ketika dalam bahaya.

9. Atmanivedanam, penyerahan diri secara total kepada-Nya.

Nawawidha Bhakti atau Navalaksana Bhakti menjabarkan mengenai varian bhakti dalam Hindu. sekaligus memberikan paradigma baru bahwa bhakti tidak hanya duduk bersila 
dipura (sembahyang), bhakti tidak hanya berisi ritualistik konvensional seperti yang selama ini kita lihat dan laksanakan dalam praktek keagamaan sehari-hari melainkan bhakti memiliki makna yang sangat luas dan dalam. Bhakti tidak semata-mata bermakna vertikal, dan individualisme namun juga vertikal dan sosial. Belajar mengenai bhakti berarti juga berfilsafat mengenai pemujaan, pelayanan dan bagaimana kita berbuat yang terbaik untuk semua makhluk hidup.

Hal ini dapat kita cermati satu demi satu dari penjelasaan mengenai Nawawidha Bhakti atau Navalaksana Bhakti di atas. Misalnya mengenai Dasya. Dasya adalah melayani Tuhan. Dalam pelayanan kepada Tuhan tidak semata-mata hanya berupa pelayanan $\mathrm{d} \mathrm{a} 1 \mathrm{a} \mathrm{m}$ a ktivitas d a $1 \mathrm{a} \mathrm{m}$ pemujaan/persembahyangan saja. Pelayanan kepada Tuhan dapat juga kita lakukan dengan jalan membantu dan menolong kepada sesama makhluk, sebagai ciptaan Tuhan, dan sebagainya. Sehingga, bhakti (Nawawidha Bhakti) selain mendidik diri untuk tulus dan taat berserah diri kepada-Nya juga mengajarkan kita untuk bagaimana menumbuh-kembangkan rasa cinta kasih, simpati dan empati kepada sesama ciptaan Beliau.

Bentuk atau contoh perwujudan bhakti di atas dapat dilihat dari pelbagai cerita, baik dalam kitab-kitab Itihasa seperti Ramayana dan Mahabharata maupun kitab-kitab Purana. Untuk memantapkan pemahaman kita tentang bhakti ini, kami kutipkan dua cerita (Titib, 2003:56-61), yaitu cerita tentang kebhaktian Hanuman kepada Sri Rama dalam ramayana dan cerita mengenai Arjuna Pramada sebagai berikut :

\section{Bhakti Hanoman Kepada Sri Rama}

Saat itu, setelah penobatan Vibhisana sebagai maharaja dan kota Lengka sudah diganti namanya menjadi Srilanka, semua pasukan Sri Rama telah kembali ke Ayodhya. Sri Rama bersama dewi Sita dan laksmana mengendarai kereta terbang bernama Manipuspaka yang merupakan hadiah dari dewa Kuvera. Setibanya di keraton Ayodhya segera dilaksanakan upacara Abhivandana, yaitu upacara syukuran atas kejayaan Sri Rama berhasil menundukkan Ravana. Pada persidangan agung yang mulia dihadiri oleh seluruh petinggi kerajaan, Sri Rama membagi-bagikan berbagai hadiah kepada siapa saja yang pernah berjasa dalam memenangkan perang untuk merebut kembali dewi Sita. Setelah setiap pejabat tinggi mendapat hadiah, selanjutnya dipanggillah Hanuman untuk menerima hadiah dari Sri Rama. Saat itu Hanuman tampil berdatang sembah, dengan sangat hormat ia menyatakan tidak bersedia lagi menerima hadiah. Alasan Hanuman, dengan Sri Rama mengijinkan dirinya sebagai abdi sang Purna Avatara, dirinya sudah mendapatkan hadiah yang tiada taranya, sebab siapa saja yang dekat dengan Tuhan Yang Maha Esa, para dewa atau avatara-Nya, seseorang menikmati kebahagiaan yang sejati.

Terhadap penolakan Hanuman ini, Sri Rama dan dewi Sita kembali mendesak Hanuman untuk bersedia 
menerima hadiah sebagai kenang-kenangan atas keberhasilan di medan perang. Demikian pula keberhasilan Hanuman sebagai duta serta keberanian dan kekuatan Hanuman menadapat pujian dari segenap yang hadir. Hanuman tidak menjawab. Saat itu dewi Sita berbisik kepada suaminya, untuk mengijinkan kalung mutiara hadiah Prabu Janaka, ayahanda dewi Sita diberikan kepada Hanuman. Sri Ramapun menyetujuinya, walaupun kalung mutiara itu memiliki arti yang istimewa bagi Sri Rama dan dewi Sita, karena dihadiahkan saat Sri Rama berhasil mematahkan busur milik dewa Siwa dalam sayembara dan berhasil m e m e n a n g k n s e r t a mempersunting dewi Sita sebagai istrinya. Saat hanuman tertunduk, Sri Rama langsung membuka kalung Dewi Sita dan $\mathrm{t}$ a m p i l e d e p a n menyerahkannya kepada Hanuman. Hanuman seperti terpaksa menerima hadiah itu. Hanuman merasa malu, seorang yang telah lama diterima sebagai abdi harus menerima hadiah, bukankah hal ini salah satu wujud kerakusan? Setelah Hanuman menerima hadiah tersebut, satu-persatu butiran mutiara itu diperhatikan oleh Hanuman, maksudnya untuk menemukan gambar Sri Rama dan Sita pada biji-biji mutiara tersebut. Ia pun tidak menemka hal itu, tanpa disadari ia menggeleng-ge lengkan kepalanya dan kemudian menggigit rangkaian mutiara itu dan melemparkannya ke tanah. Hadirin tercengang dan gemas menyaksikan kejadian itu. Panglima Sugriva langsung marah dan membentak Hanuman. "Hai Hanuman, engkau kera hina tidak tahu diri, kelakuanmu itu memalukan, kuhancurkan wajahmu! Kau telah hina persidangan yang agung ini. Ia berdiri tegak sambil mengepalkan tangan hendak memukul Hanuman. Bila saja tidak di depan persidangan yang mulia itu, Sugriva pasti sudah menempeleng muka Hanuman. Sugriva sangat geram, tubuhnya gemetar menahan marah.

$\mathrm{Pad}$ a s a t y a n $\mathrm{g}$ menegangkan itu, Sri Rama dan Sita tersenyum dan memandang Sugriva yang sedang marah. Demikian tatapan Sri Rama dan Sita menyapu wajah Sugriva, saat itu pula emosi dan kemarahan Sugriva lenyap. Sri Rama dan dewi Sita benar-benar mengalirkan pancaran kasih yang tiada taranya. Selanjutnya Sri Rama mendatangi Hanuman dan menepuk bahunya : “ Engkau seperti anak kecil, mengapa lakukan hal itu?". Maaf tuan Sri Rama dan ibu dewi Sita, hamba telah mengecewakan persidangan yang mulia ini. Memang hamba seekor kera yang hina, tetapi hamba kira diri hamba tidak lebih rendah dari seorang manusia. Bagi hamba dengan diijinkan sebagai abdi, hamba sudah bahagia, karena ketika hamba dekat dengan tuan dan ibu sebagai perwujudan Avatara Tuhan Yang Maha Esa dan Dewi Laksmi, saat itu pula kebahagiaan tiada taranya hamba peroleh dari tuan. Bukankah dengan pemberian hadiah ini hamba menunjukkan kerakusan hamba?". 
Sri Rama kembali menepuk bahu Hanuman. "tidak! Engkau tidak rakus. Lalu apa yang engkau minta Hanuman? Katakanlah, jangan seperti anak kecil !". "Baiklah tuan dan ibu dewi Sita, bila hamba boleh meminta lagi, ijinkanlah hamba senantiasa dekat tidak saja secara jasmaniah tetapi tuan dan ibu dewi Sita hendaknya selalu berada di hati kami. Untuk itu sudikah tuan Sri Rama dan ibu dewi Sita untuk berstana pada jantung hati kami. Pada singgasana bunga hati kami. Bila tuan dan ibu dewi Sita berkenan bersthana, maka itulah hadiah yang senantiasa hamba mohon".

Sri Rama selanjutnya berdiri tegak dan bersabda : "hai Hanuman dan hadirin yang tercinta dan supaya di dengar pula oleh seluruh jagat raya. Siapa saja yang maju selangkah menghadap aku dan mau mendekatkan dirinya serta membuka pintu hatinya. Aku akan datang sepuluh langkah mendekati mereka, masuk ke dalam hatinya dan memberikan kebahagiaan yang sejati tiada taranya!. Mendengar sabda Sri Rama demikian merdu dan menggetarkan alam semesta. Hanuman dengan mencium kaki Sri Rama terlebih dahulu, kemudian menegakkan dadanya. Dengan kekuatan "bayubajra", bagaikan kekuatan petir, tibatiba dengan kukunya dengan kukunya yang tajam ia menoreh dadanya. Dan dengan tenaga yang dahsyat, tiba-tiba ia merobek dadanya, darah berhamburan keberbagai arah. Saat itu pula Sri Rama dan dewi Sita hilang dari singgasana kencananya yang indah. Suasana menjadi hening dan terdengar mantra-mantra para dewa dan rsi-rsi surga dengan taburan bunga harum semerbak, nampaklah cahaya gemerlapan pada dada Hanuman yang menganga lebar. Pada cahaya itu kemudian nampak sebuah singgasana emas di atas padma hati Hanuman. Ketika itu Kelihatan Sri Rama dan dewi Sita duduk melambaikan tangan dengan sikap abhaya dan varamudra, yaitu sikap tangan menjauhkan serta menolak bencana dan memebri hadiah. Hadirin mengucapkan jaya-jaya Sri Rama, jaya-jaya dewi Sita. Setelah suasana hening kembali. Hanumanpun menutup dadanya, tidak nampak ada luka dan tibatiba Sri Rama dan dewi Sita sudah kembali bersthana pada singgasana kencana di depan persidangan.

\section{Demikian cerita singkat dari} kisah Ramayana yang memberikan pendidikan secara simbolis, bila dihati kita telah bersthana sang Avatara, para dewa manifestasi Tuhan Yang Maha Esa, maka niscaya kebahagiaan akan selalu berada dalam diri kita. Berbagai upacara termasuk piodalan/pujawali dan lain-lain mengandung makna untuk mendekatkan diri, maka Tuhan Yang Maha Esa dalam wujud-Nya sebagai Anandarupa, yakni kebahagiaan yang sejati akan turun dan memberikan kebahagiaan yang tak terhingga kepada kita. 


\subsection{Arti dan Jenis Basarah}

Basarah berarti kebhaktian yang dilaksanakan pada hari kamis atau malam jumat di Balai Basarah atau Rumah Ibadat, dihadiri oleh seluruh umat Kaharingan. Basarah mengajarkan sikap hidup, agar umat Kaharingan selalu dilindungi, ditolong, dikandung oleh ajaran, kuasa, kuat kuasa Ranying Hatalla (Riwut, Maneser Panatau ...., hal. 543).

Basarah juga diartikan sebagai ungkapan rasa syukur atas segala nikmat yang diberikan Ranying Hatalla kepada umat manusia. Basarah disebut pula Sembahyang yakni ritual untuk memuja dan memuji kebesaran dan kekuasaan Ranying Hatalla Langit. Pagi siang, sore kita berdoa agar kita diberi kekuatan, keselamatan dalam setiap pekerjaan (Lembaga pengembangan Tandak ...., 2003:1).

Secara etimologi kata Basarah berasal dari kata "sarah" yang artinya "menyerah" atau "pasrah". Kata Basarah seringkali dipakai dalam bahasa Dayak Ngaju sehari-hari, misalnya "Keleh basarah dengan Tuhan" (lebih baik berserah kepada Tuhan), atau "Ikei basarah dengan uka maatuh taloh handiai (Kami pasrah kepadamu untuk mengatur segalanya). Basarah bisa diartikan "berserah", "pasrah", atau "menyerahkan". Pada awalnya acara Basarah dilakukan pada puncak acara Tiwah yaitu pada saat Balian Balaku
Untung. Pada saat itu orang-orang manyarah (menyerahkan) uang, beras atau benda-benda lainnya kepada keluarga yang mengadakan Tiwah agar mereka juga mendapatkan berkah dari ritual yang diadakan. Pada tahun 1972, dalam musyawarah Alim Ulama Kaharingan se Kalimantan Tengah, kata Basarah diambil menjadi nama ibadah atau kebaktian Kaharingan.

Para penganut Kaharingan melihat bahwa kata Basarah merupakan singkatan (akronim) dari tiga kalimat berikut :

o BASAlungkem Ajaran Ranying Hatalla: Bersatupadu dengan Ajaran Ranying Hatalla. Artinya dilindungi oleh ajaran Ranying Hatalla.

o BASAlumpuk Asin Ranying Hatalla: Berintikan Kasih Ranying Hatalla. Artinya ditolong oleh kasih sayang Ranying Hatalla.

o BASAlupu Aturan Ranying Hatalla: Berbalutkan Aturan Ranying Hatalla. Artinya dipenuhi/dilingkupi aturan/hukum Ranying Hatalla.

Patut diketahui bahwa terdapat beberapa macam Basarah, yaitu :

- Basarah rutin yang diadakan satu kali seminggu setiap hari Kamis atau malam Jumat

- Basarah keluarga atau rumah tangga yang diadakan di rumah keluarga Kaharingan yang dilakukan secara 
bergantian atau sesuai permintaan.

- Basarah kematian atau penguburan

- Basarah perkawinan

- Basarah Nahunan yaitu memberi nama dan memandikan bayi

- Basarah untuk memulai upacara keagamaan (Mahin, 2009:79-80).

\subsection{Tata Pelaksanaan Basarah}

Adapun susunan acara dala pelaksanaan Basarah adalah sebagai berikut:

o Manggaru Sangku Tambak Raja

o Doa Tamparan Basarah

o Kandayu Manyarah Sangku

Tambak Raja

o Mambasa Pampeteh Ranying

Hatalla Huang Kitab Panaturan

o Kandayu Matang Kayu Erang

o Mandehen Pampeteh Ranying

Hatalla Langit

o Kandayu Parawei

o Doa Kahapus Basarah

o Mambuwur Hambaruan, Mamantis

Undus, Manapung Tawar, Tuntang

Tanteluh Manuk Akan Hapa

Mamalas, Tau Kea Impahinje

Huang Tampung Tawar.

\subsection{Sarana-sarana/Paramun Basarah}

Dalam pelaksanaan Basarah, terdapat berbagai macam sarana atau peralatan ritual tersebut, yang kesemuanya sarat dengan nilai simbolik terkait dengan pemujaan kepada
Ranying Hatalla Langit. Adapun saranasarana tersebut antara lain : 1) Sangku, 2) Behas, 3) Bulu ekor Tingang, 4) Sipa dan Ruku, 5) Duit Singah Hambaruan, 6) Undus Tanak, 7) Behas Hambaruan, 8) Tampung Tawar, 9) Parapem Garu Manyan, 10) Benang Lapik Sangku, 11) Tanteluh Manuk, 12) Kambang.

\subsection{Nilai-Nilai dalam Upacara Basarah \\ Basarah merupakan ritual penting} bagi umat Hindu Kaharingan, khususnya di daerah Kalimantan Tengah. Basarah tidak hanya bersifat ritualistik-religius yang hanya berkorelasi dengan Ranying Hatalla Langit, Tuhan Yang Maha Esa, namun Basarah juga memiliki kandungan lain. Nilai yang sangat berharga bagi kehidupan sosial masyarakat, diantaranya :

\subsubsection{Nilai Religius}

Basarah berarti "berserah", "pasrah", atau "menyerahkan". Basarah memiliki relasi vertikal, yakni berkaitan antara manusia dengan Tuhan, Ranying Hatalla Langit. Basarah adalah aktualisasi rasa bhakti umat Hindu Kaharingan dengan Tuhan. Sikap bhakti ini merupakan pengakuan manusia atas kuasa dan kebesaran Tuhan sebagai sumber segala kehidupan di semesta raya ini. Kitab Panaturan Pasal 1 ayat 1-3 menyatakan sebagai berikut:

Hemben huran tutuk panambalun 
tambun,

Baya ije atun ije tamparan taluh handiai,

Jai panapatuk sukup simpan,

Hasambalut umba ambun ije dia baja huntun tanduk,

Basakupa dengan enun isen baterus kening,

Hinje hasambalut umba kahain kuasae belum japa jimat maharing

Terjemahan :

Jaman dahulu kala, permulaan segala masa, Ia adalah awal segala kejadian, Ia Yang Maha Sempurna diliputi oleh kekuatan dan kuasanya-Nya, menyatu di dalam keagungan dan kemulian-Nya.

Ie ije tamparan taluh handiai mukei kahain kuasae,

Jai panapatuk sukup simpan murai japa jimat tanteng,

Hayak auh Nyahu Batengkung Ngaruntung Langit,

Homboh Malentar Kilat Basiring

Hawun,

Palus ambun ije dia bajahuntun tanduk,

Enun basansinep isen baterus kening,

Badandang manjadi balawa hayakbarasih,

Lenda-lendang, linge-lingei,

Hayak Ie hamauh mananggare arepe: Aku Tuh Ranying Hatalla, Mijen Balai Bulau Napatah Hintan, Balai Hintan Napatah bulau,

Mijen Tasik Malambung Bulau, marung Laut Bapantan Hintan

Terjemahan :

Ia adalah awal segala kejadian, memperlihatkan kebesaran dan kekuasan-Nya. Ia Yang Maha Sempurna; menyat akan keagungan dan kemuliaan-Nya, dan bersama dengan itu, bergetarlah alam semesta alam, laksanana guntur menggelegar langit, petir dan halilintar menggetar alam semesta, maka memancarlah cahaya terang yang bersih suci, menghalau kegelapan alam, serta Ia yang awal segala kejadian, berfirman dan menyatakan dir-Nya: Aku Inilah Ranying Hatalla yang bertahta pada Balai Bulau Napatah Hintan, Balai Hintan Napatah Bulau, dikelilingi Tasik Malambung,

Bulau, Laut Bapantan Hintan

Aku tuh Ranying Hatalla ije paling kuasa,

tamparan taluh handiai tuntang kahapuse, tuntang kalawa jetuh iete kalawa pambelum,

ije inanggare-Ku gangguranan arae bagare Hintan Kaharingan

Terjemahan :

Aku inilah Ranying Hatalla Yang Maha Kuasa, awal dan akhir segala kejadian, dan cahaya kemuliaan-Ku yang terang, bersih dan suci, adalah cahaya kehidupan yang kekal abadi, dan Aku sebut ia Hintan Kaharingan (Panaturan, 2009:1).

Ritual Basarah melambangkan kepatuhan manusia dan aktualisasi pengakuan keagungan Tuhan, Ranying Hatalla Langit. Ini adalah saat dimana, seluruh umat Hindu Kaharingan berelasi secara batin kepada Tuhan, momen menyampaikan syukur dan suka cita atas segala karunia Beliau, seraya menyampaikan permohonan atas segala 
kekhilafan kita sebagai manusia yang penuh keterbatasan. Permohonan maaf atas segala kesalahan yang di timbulkan dari pikiran, ucapan dan tingkah laku yang tidak baik dan menimbulkan ketidak bahagiaan kepada siapapun makhluk Tuhan.

Selain itu Basarah Juga biasanya berisi mengenai permohonan atau doa yang disampaikan kepada Ranying Hatalla Langit agar senantiasa memberi keberkahan, perlindungan, keselamatan, rejeki, menghindarkan dari segala hal buruk, dan hal-hal lain yang dianggap perlu untk disampaikan kehadapan Ranying Hatalla terkait dengan kebutuhan diri manusia itu sendiri. Karena, umat Hindu kaharingan meyakini bahwa hanya Beliau Ranying Hatalla Langit yang dapat memenuhi segala hal, karena Beliau adalah Maha Kuasa dan memiliki kuasa atas segalanya dalam kehidupan ini.

\subsubsection{Nilai Sosial}

Ritual Basarah bersifat kolektif. Dalam pelaksanaan Basarah, telah ada pembagian tugas sesuai dengan runtutan acara. Pembagian tugas itu antara lain: 1) Petugas Pemimpin Basarah, 2) Petugas Manggaru sangku tambak raja, 3) Petugas Doa tamparan Basarah, 4) Petugas Kandayu Manyarah Sangku Tambak Raja, 5) Petugas Mambasa Pampeteh Ranying Hatalla Huang Kitab Panaturan, 6) Petugas Kandayu Matang Kayu Erang, 7) Patugas Mandehen
Pampeteh Ranying Hatalla Langit, 8) Petugas Kandayu Parawei, 9) Petugas menyampaikan Doa Kahapus Basarah, 10) Petugas Mambuwur Hambaruan, 11) Petugas Mamantis Undus, 12) Petugas Manapung Tawar, 13) Petugas Tuntang Tanteluh Manuk Akan Hapa Mamalas, Tau Kea Impahinje Huang Tampung Tawar.

Dari situasi pembagian tugas yang telah terbagi di atas, kiranya telah dapat dimengerti bahwa ritual Basarahs esungguhnya adalah tentang kolektivitas. Basarah sarat dengan nilainilai kebersamaan. Di dalamnya terjadi $\mathrm{p}$ roses interaksi, komunikasi, kerjasama, kerukunan dan keimanan.

Basarah tidak hanya tentang Tuhan, Ranying Hatalla dalam korelasi dengan manusia, melainkan Basarah juga tentang relasi antar manusia, melainkan visualisasi dan aktualisasi dari nilai-nilai perdamaian, harmoni, cinta kasih, dan persaudaraan manusia. Basarah adalah momentum dimana setiap umat terlibat dalam sebuah interaksi dan komunikasi yang intensif, ini adalah wahana umat menyatukan diri, berbaur, berkomunikasi, berbagi tentang banyak dalam tema-tema yang sangat terbuka. Proses-proses konsolidasi, rekonsiliasi, rehabilitasi, komunikasi, diskusi, terjadi dalam suasana ini. Merupakan situasi yang sungguh potensial untuk menata kehidupan intern umat beragama 
menuju pada perdamaian diri, sosial, dan antara umat beragama.

Contoh riil dari uktualisasi nilainilai di atas yaitu :

ii Interaksi, komunikasi, kebersamaan umat dalam mempersiapkan Basarah, misalnya mempersiapkan sarana dan prasarana Basarah.

ü Interaksi, komunikasi, kebersamaan umat dalam mempersiapkan tempat basarah, misalnya membersihkan tempat basarah, menempatkan posisi sarana dan prasarana basarah.

ui Interaksi, komunikasi, kebersamaan umat dalam membagi petugas-petugas dalam pelaksanaan Basarah. Misalnya : Siapa yang menjadi petugas Pemimpin Basarah, petugas Manggaru sangku tambak raja, petugas doa tamparan Basarah, petugas Kandayu Manyarah Sangku Tambak Raja, petugas Mambasa Pampeteh Ranying Hatalla Huang Kitab Panaturan, petugas Kandayu Matang Kayu Erang, petugas Mandehen Pampeteh Ranying Hatalla Langit, Petugas Kandayu $\mathrm{P}$ a r a w e i, $\quad$ pe t u g a s menyampaikan Doa Kahapus Basarah, petugas Mambuwur Hambaruan, petugas Mamantis Undus, Petugas Manapung
Tawar, dan petugas Tuntang Tanteluh Manuk Akan Hapa Mamalas, Tau Kea Impahinje Huang Tampung Tawar.

ü Interaksi, komunikasi, kebersamaan umat dalam mempersiapkan hidangan kalau memang tersedia konsumsi bagi umat yang sedang melaksanakan Basarah.

Ini adalah contoh-contoh sederhana tentang interaksi, komunikasi, kerjasama, kebersamaan, dan kerukunan yang dialami dan dipelajari dalam pelaksanaan Basarah.

\subsubsection{Nilai Pendidikan}

Basarah tidak hanya bernilai religius, sosial tetapi juga edukatif bagi pelaksananya (umat). Inilah nilai-nilai yang sangat elementer dalam rangka $p$ erwujudan dinamika kerukunani nternal maupun eksternal umat beragama. Khususnya dalam dinamika internal umat, basarah memiliki peran yang sangat sentral. Proses edukasi itu meliputi :

\section{Edukasi nilai-nilai religius, yaitu menyangkut mengenai pengetahuan, filsafat, etika dan ritual keagamaan. Ini adalah saat dimana pada acara Mandehen Pampeteh Ranying Hatalla Langit. Mandehen Pampeteh Ranying Hatalla Langit adalah dimana sabda Ranying Hatalla}


Langit disampaikan dan dikupas dalam basarah tersebut. Hal ini disampaikan oleh petugas pandehen (orang yang bertugas ceramah) dalam basarah tersebut. Penceramah tersebut kan mengupas ayatayat suci yang telah terlebih dahulu dilantunkan dalam Mambasa Pampeteh Ranying Hatalla Huang Kitab Panaturan, yaitu melantunkan ayat-ayat panaturan. Kajian filosofis tentang ayat tersebut, maksud dan tujuan serta manfaatnya akan di sampaikan secara tuntas. Inilah saat penting bagi peserta Basarah, karena dalam Mandehen Pampeteh Ranying Hatalla Langit peserta basarah memperoleh pengetahuan penting mengenai keimanan mereka, ketuhanan mereka, ajaran etika mereka, sekaligus ritual keagamaan. Pengetahuan tersebut akan memupuk keimanan, serta menjadi jawaban atas segala pertanyaan-pertanyaan mereka selama ini.

- Edukasi nilai-nilai sosial

yaitu dalam pelaksanaan Basarah tersebut tidak hanya menjadi sarana pendalaman pengetahuan dalam hal keagamaan saja, melainkan juga ini adalah momen istimewa bagi umat untuk belajar bagaimana lebur dalam interaksi, komunikasi, dialog, tentang tema-tema yang tidak hanya terkait dengan keagamaan saja, melainkan juga yang berkaitan dengan tema-tema kerukunan, keharmonisan, kebersamaan, korelasi antara agama dengan kehidupan sosial, korelasi antara agama dengan kebudayaan, bahkan diskusi tentan tema yang tetapi yang meyangkut mengenai upayaupaya konsolidasi, rehabilitasi, dan revitalisasi komunikasi keumatan dlam rangka menggapai dinamika kerukunan umat intern, yang nantinya juga berujung pada dinamika kerukunan antara manusia dan antar umat beragama.

Tid a k m e n u t u p kemungkinan, tema-tema dalam pendehen juga dikorelasikan dengan edukasi sosial, sehingga pengetahuan keagamaan tidak hanya dalam tataran ide, teoretis, retorika, n a m u n ben a r-ben ar terinternalisasi dalam tataran praktis. Sehingga, agama 
menjadi instrumen yang efektif dalam proses komunikasi dan interaksi menuju pada dinamikan keharmonisan sosial.

contohnya : Bagaimana nilai-nilai etika, humanisme, cinta kasih dalam ajaran Kitab Suci Umat Hindu Kaharingan dikorelasikan dengan tataran raktis dalam rangka bagaimana memahami dan membina relasi dengan sesama intern umat Hindu yang berbeda-beda suku, ritual, norma-norma, etika, bahasa? Bagaimana relasi nilai-nilai filosofi agama dengan praktik-praktik beragama yang beragama dalam kalangan Hindu yang disebabkan perbedaan adat istiadat, norma, etika? Bagaimana agama menjawab masala-masalah sosial, seperti kemajemukan? Perbedaan? Pandangan terhadap orang lain? Perlakuan bagi makhluk lain? Bagaimana memandang orang dalam keyakinan yang berbeda? dan sebagainya.

Dengan demikian agama dalam kaitan nilai sosial dan pembangunan karakter dapat benar terealisasikan. Sehingga situasi damai akan benar-benar diwujudkan, dan bukan sekedar impian. Dengan demikian, pelecehan atas praktik-praktik keyakinan yang berbeda tidak, diskrimani agama, dan tindakan-tndakan ketidakadilan yang mengatasnamakan agama tidak akan pernah terjadi. Dan ini memerlukan upaya dari diri sendiri, dan tugas dari masingmasing agama.

\section{SIMPULAN}

Basarah merupakan aktivitas keagamaan yang sangat penting bagi umat Hindu Kaharingan di Kalimantan, khususnya di Kalimantan Tengah. Basarah tidak tanda kerasrahan manusia kepada Ranying Hatalla Langit, Tuhan, melainkan juga bukti pengakuan umat Hindu Kaharingan akan keberadaan dan kuasa Tuhan sebagai sumber segala kehidupan. Pada akhirnya, Basarah tidak hanya berdimensi religius, melainkan juga sosial dan edukasi.

\section{DAFTAR PUSTAKA}

Anonim. 2003. Panaturan. Palangka Raya:Majelis Besar Agama Hindu Kaharingan (MB-AHK) Pusat Palangka Raya

Bimbingan Masyarakat Hindu Kantor Wilayah Kementrian Agama Provinsi Kalimantan Tengah 2012. Kandayu (Kidung Persembahyangan) 
Bimas Hindu Kanwil Dep. Agama Provinsi Kalimantan Tengah. 2009 . Panaturan. Denpasar:Widya Dharma

Darmadi, Hamid. 2007. Dasar Konsep Pendidikan Moral. Bandung:Alfabeta.

Depdiknas. 2008. Kamus Besar Bahasa Indonesia Edisi Keempat. Jakarta : PT. Gramedia Pustaka Utama

Gde Puja, MA dan Tjokkorda Rai Sudhartha, M A, 2002 . Manawadharmasastra. Jakarta.

Lembaga Pengembangan Tandak dan Upacara Keagamaan Umat Agama Hindu Kaharingan. 2003. Buku Pelajaran Agama Hindu Kaharingan. Palangka Raya

Mahin, $\quad$ a rko. 2009. "Kaharingan:Dinamika Agama Dayak di Kalimantan". (Desertasi).Jakarta:Program Pasca Sarjana Antropologi Universitas Indonesia Fakultas Ilmu sosial dan politik.

Nau, Rangkap I. 2003. Buku Kandayu (Penuntun Persembahyangan). MB-AHKP Palangkaraya

Prabhupada, AC Bhaktivedanta Swami. 2006. Bhagavad-gita Menurut Aslinya. Jakarta : Hanuman Sakti, Lisensi The Bhaktivedanta Book Trust International, Inc.

Radhakrishnan, S. 1989. Upanisad Utama. Denpasar:Yayasan Dharma Sarathi

Riwut, Tjilik. (2003). Maneser Panatau Tatu Hiang Menyelami Kekayaan Leluhur. Pusaka Lima:Palangka Raya

Wiana, I Ketut. 2007. Sembahyang
Menurut Hindu. Surabaya:Paramita 
Jurnal Penerangan Agama Hindu Vol. 16 No. 2, 2018 